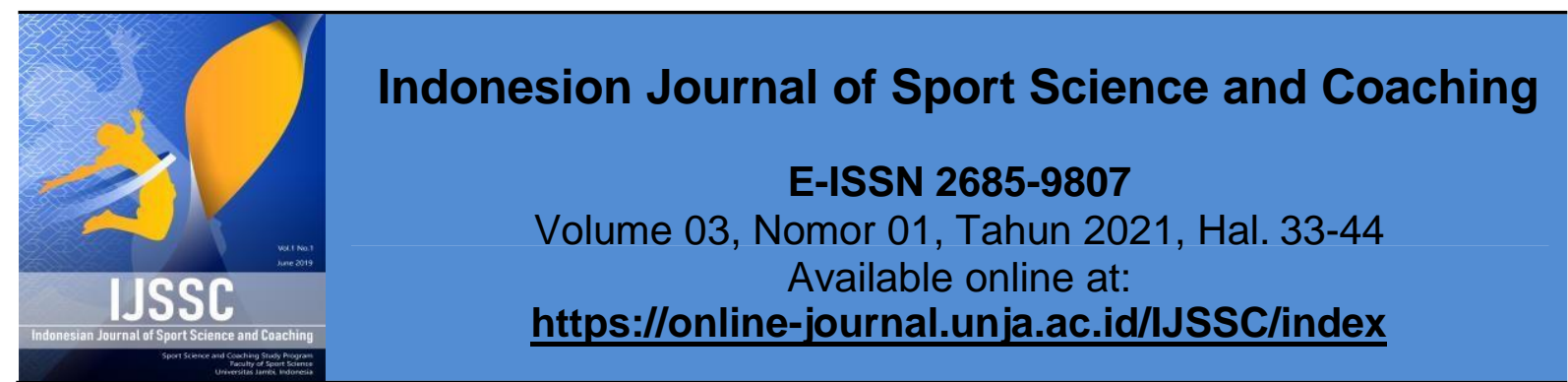

Research Article OPEN ACCESS

\title{
Efektivitas Pembelajaran Daring pada Kegiatan Belajar Mengajar Praktik dalam Mata Pelajaran Pendidikan Jasmani di SMP N 4 Sungai Penuh
}

\section{(The Effectiveness Of Blood Learning in Teaching Learning Activities in Physical Education Study in SMP N 4 Sungai Penuh)}

\author{
Widian Pratama ${ }^{1}$, Boy Indrayana ${ }^{2}$ \\ Pendidikan Olahraga dan Kesehatan, Universitas Jambi, Indonesia ${ }^{1}$ \\ Kepelatihan Olahraga, Universitas Jambi, Indonesia ${ }^{2}$ \\ Corresponding Author: widian.pratama99@gmail.com,
}

\begin{tabular}{|c|c|}
\hline Informasi Artikel & ABSTRACT \\
\hline Submit: $12-02-2021$ & $\begin{array}{l}\text { This study aims to see how the effectiveness of online learning } \\
\text { in practical teaching and learning activities in physical education } \\
\text { subjects at SMP N } 4 \text { Sungai Penuh. This research was conducted at } \\
\text { SMP N } 4 \text { Sungai Penuh in December } 2020 \text {. The research data was } \\
\text { obtained by distributing online questionnaires using Goggle Forms to } \\
\text { students. After the questionnaire was returned, the data were analyzed } \\
\text { descriptively and quantitatively with the percentage formula. The } \\
\text { results showed that the low effectiveness of online learning in practical } \\
\text { teaching and learning activities in physical education subjects at SMP } \\
N 4 \text { Sungai Penuh. This can be seen from the results of the research } \\
\text { described in several indicators, namely the internet access indicator } \\
\text { with a total percentage of } 48,5 \% \text {. Then, the indicator of understanding } \\
\text { the material in online learning was } 47,5 \% \text {. Furthermore, the indicator } \\
\text { of effectiveness in online learning is } 48,1 \% \text {. Then the indicators of } \\
\text { online learning implementation in practical teaching and learning } \\
\text { activities amounted to } 46,6 \% \text {. From the four indicators described } \\
\text { above, an average value of } 47,7 \% \text { can be taken, from this } \\
\text { percentage it can be concluded that the effectiveness of online } \\
\text { learning in practical teaching and learning activities in physical } \\
\text { education subjects at SMP } 44 \text { Sungai Penuh is low. From the results } \\
\text { of this study, it is suggested that teachers be more creative and } \\
\text { innovative in providing physical education learning online. In } \\
\text { addition, teachers as role holders in learning activities should improve } \\
\text { their teaching skills, use media, and vary the right strategies in } \\
\text { learning, so that online learning in teaching and learning activities in } \\
\text { the future practice can be better. } \\
\text { Keywords: Effectiveness, Online, Practice }\end{array}$ \\
\hline Penerbit & ABSTRAk \\
\hline $\begin{array}{l}\text { Jurusan Pendidikan } \\
\text { Olahraga dan Kepelatihan } \\
\text { FKIP Universitas Jambi } \\
\text { Jambi- Indonesia }\end{array}$ & $\begin{array}{l}\text { Penelitian ini bertujuan untuk melihat bagaimana efektivitas } \\
\text { pembelajaran daring pada kegiatan belajar mengajar praktik dalam } \\
\text { mata pelajaran pendidikan jasmani di SMP N } 4 \text { Sungai Penuh. } \\
\text { Penelitian ini dilakukan di SMP N } 4 \text { Sungai Penuh pada desember } \\
\text { 2020. Data penelitian diperoleh dengan cara menyebarkan angket } \\
\text { online menggunakan Goggle Formulir kepada siswa. Setelah }\end{array}$ \\
\hline
\end{tabular}


angket dikembalikan, data dianalisis secara deskriptif kuantitatif dengan rumus persentase. Hasil penelitian menunjukkan bahwa rendahnya efektivitas pembelajaran daring pada kegiatan belajar mengajar praktik dalam mata pelajaran pendidikan jasmani di SMP N 4 Sungai penuh. Hal ini terlihat dari hasil penelitian yang dijelaskan dalam beberapa indikator yaitu indikator akses internet dengan jumlah persentase sebesar $48,5 \%$. Kemudian, pada indikator pemahaman materi dalam pembelajaran daring sebesar $47,5 \%$. Selanjutnya pada indikator keefektifan dalam pembelajaran daring sebesar 48,1\%. Kemudian pada indikator implementasi pembelajaran daring pada kegiatan belajar mengajar praktik sebesar 46,6\%. Dari keempat indikator yang telah dijelaskan diatas dapat diambil nilai rata-rata sebesar 47,7\%, dari persentase tersebut disimpulkan bahwa efektivitas pembelajaran daring pada kegiatan belajar mengajar praktik dalam mata pelajaran pendidikan jasmani di SMP $\mathrm{N} 4$ Sungai Penuh tergolong rendah. Dari hasil penelitian ini disarankan agar guru dapat lebih kreatif dan inovatif dalam memberikan pembelajaran pendidikan jasmani secara daring. Di samping itu, guru sebagai pemegang peran dalam kegiatan pembelajaran mestinya meningkatkan kemampuan mengajar, penggunaan media, dan memvariasikan strategi yang tepat dalam pembelajaran, sehingga pembelajaran daring pada kegiatan belajar mengajar praktik kedepannya dapat lebih baik.

Kata Kunci : Efektifitas, daring, praktik

This Indonesian Journal of Sport Science and Coaching is licensed under a CC BY-NC-SA (Creative Commons Attribution-ShareAlike 4.0 International License)

\section{PENDAHULUAN}

Berkaitan dengan adanya wabah Covid-19 pada awal tahun 2020, hal ini memberikan pengaruh besar terhadap aspek-aspek, baik aspek ekonomi, sosial, budaya, bahkan pendidikan. Pemerintah kemudian mengeluarkan himbauan untuk melakukan kegiatan pembelajaran dari rumah, sesuai dengan surat edaran Kementerian Pendidikan dan Kebudayaan (Kemendikbud) No. 4 tahun 2020 tentang pelaksanaan kebijakan pendidikan dalam masa darurat penyebara Coronavirus Disease (Covid-19), menyatakan bahwa belajar dari rumah melalui pembelajaran daring/jarak jauh dilaksankan untuk memberikan pembelajaran yang bermakna bagi siswa.

Dengan adanya himbauan tersebut, maka proses pembelajaran pun dilakukan dari rumah dengan memanfaatkan teknologi dan media internet. Beberapa institusi pendidikan yang sebelumnya melakukan pembelajaran tatap muka di sekolah masing-masing, kini harus mengadaptasi model pembelajaran $e$ learning atau yang biasa disebut pembelajaran daring.

Ditinjau dari konten dan mata pelajaran yang diajarkan di sekolah pada masa pandemi, dapat dikategorikan dalam dua kelompok. Kelompok pertama adalah kelompok mata pelajaran yang didominasi oleh teori dan sedikit praktik, sementara kelompok kedua didominasi oleh praktik dengan sedikit teori. Kedua kelompok ini sangat berbeda dalam penerapan pembelajaran online. Pendidikan jasmani merupakan disiplin ilmu yang masuk pada kategori kedua, dengan dominasi praktik pada aktivitas fisik.

Dimasa pandemi, pembelajaran teoritis memang tidak terlalu menjadi kendala. Namun, pembelajaran praktik mengalami kendala yang serius. Salah satu pelajaran yang banyak menerapkan pembelajaran praktik adalah pelajaran pendidikan jasmani. Dalam pendidikan jasmani banyak menerapkan pembelajaran secara organik, neuromuscular, intelektual, sosial, kultural, emosional, dan 
estetika yang dihasilkan dari proses pemilihan berbagai aktivitas jasmani. Walau ditengah pandemi, tidak menjadi alasan pembelajaran ini ditiadakan. Pendidikan jasmani sangat penting untuk dipelajari peserta didik, karena dengan pengetahuan mengenai praktik olahraga, peserta didik dapat membentengi diri, salah satunya dengan meningkatkan daya tahan tubuh (imunitas) untuk mencegah virus Corona.

Kondisi ini akan menyulitkan baik bagi guru maupun siswa dan orang tua siswa. Dari guruakan kesulitan menyiapkan bahan ajar, media, dan pengawasan. Dari siswa belum terbiasa dengan pola daring, tugas yang menumpuk, motivasi belajar yang menurun karena akan jenuh dan bosan. Dari segi orang tua akan kerepotan dalam membantu anaknya dalam mempersiapkan media atau gadget, membimbing, dan mengarahkan dalam mengerjakan tugas dari guru dan memotivasi serta mengawasi anaknya dalam mengikuti pelajaran (Indrayana \& Ali, 2020: 139-140).

Kendala lain yaitu jaringan internet yang masih kurang, berbeda dengan kota-kota besar yang jaringan internetnya lancar. Sebaliknya didaerah, jaringan internet masih kurang baik. Dengan berbagai keterbatasan tersebut, pendidikan jasmani dengan sendirinya menemui berbagai hambatan dan kendala di masa pandemi Covid-19. Akan tetapi, bagaimana implementasi dan ketercapaian pembelajaran pendidikan jasmani melalui pembelajaran daring pada siswa agar dapat berjalan sebagaimana mestinya.

\section{METODE PENELITIAN}

Penelitian ini dilaksanakan di SMP N 4 Sungai Penuh. Waktu penelitian dilaksanankan pada semester ganjil di bulan desember 2020. Metode penelitian yang digunakan dalam penelitian ini adalah metode deskriptif dengan menggunakan data kuantitatif, ialah suatu metode penelitian yang digunakan untuk membuat gambaran secara sistematik, faktual, dan akurat mengenai fakta serta hubungan antar variabel yang diselidiki pada masa sekarang.

Teknik pengambilan sampel pada penelitian ini menggunakan total sampling. Menurut Sugiyono (2009: 63), total sampling adalah teknik pengambilan sampel dimana jumlah sampel sama dengan populasi. Oleh karena itu, dari populasi sebanyak 100 orang siswa/siswi kelas VIII di SMP N 4 Sungai Penuh, maka seluruhnya dijadikan sebagai sampel penelitian.

Teknik pengumpulan data yang digunakan dalam penelitian ini adalah menggunakan metode survei. Penelitian ini berusaha untuk mendeskripsikan suatu peristiwa tanpa memberikan perlakuan khusus terhadap peristiwa tersebut. Dalam penelitian ini, peneliti tidak memberikan perlakuan khusus terhadap sampel yang digunakan sehingga tidak menggunakan kelas kontrol atau kelas eksperimen.

Instrumen atau alat yang digunakan dalam penelitian ini berupa kuesioner/angket. Kuesioner/angket digunakan untuk menyelidiki pendapat subjek mengenai suatu hal atau untuk mengungkapkan kepada responden. Menurut Sugiyono (2009: 142), kuesioner merupakan teknik pengumpulan data yang dilakukan dengan cara memberi seperangkat pertanyaan atau peryataan tertulis kepada responden untuk dijawabnya. Kuesioner yang digunakan oleh peneliti sebagai instrumen penelitian adalah dengan kuesioner tertutup dengan menggunakan penskoran menggunakan skala likert.

Validasi dalam instrument diperoleh melalui validitas isi (content validity) dengan cara pendapat dari ahli (expert judgement) yakni oleh dosen yang memiliki keahlian dalam bidang pendidikan olahraga, untuk melihat kesesuaian standar isi yang ada didalam instrument. Setelah pendapat dari ahli selesai maka langkah selanjutnya adalah dengan menguji coba instrument, yaitu menghitung validitas soal. Validitas soal dapat dihitung dengan menggunakan rumus korelasi 
Product Moment, dengan dasar keputusan jika rhitung > rtabel maka dinyatakan valid, begitu pula sebaliknya jika rhitung $<$ rtabel dengan taraf signifikan $5 \%$ maka dinyatakan tidak valid dan untuk menentukan realibilitas angket dalam penelitian ini digunakan perhitungan statistik degan rumus Cronbach Alpha dengan dasar keputusan bahwa nilai $\mathrm{r} 11>0,600$ maka data dinyatakan reliabel.

Data dalam penelitian ini dianalisis dengan rumus:

$$
\begin{aligned}
& \text { NP }=\frac{\boldsymbol{R}}{\boldsymbol{S M}} \times \mathbf{1 0 0 \%} \\
& \text { Keterangan: } \\
& \text { NP } \quad: \text { Persentase (\%) } \\
& \text { R } \quad \text { :Skor Total } \\
& \text { SM }
\end{aligned}
$$

Sumber: Arikunto (2015: 41).

Setelah didapatkan nilai dengan menjumlah skor yang diperoleh kemudian direkapitulasi dengan cara mengalikan dengan banyaknya responden yang menjawab setiap alternatif jawaban, lalu menghitung jumlah skor ideal untuk skor tertinggi dan skor terendah.

Menurut Sudijono (2005: 52), perhitungan distribusi frekuensidilakukan dengan menggunakan rumus sebagai berikut:

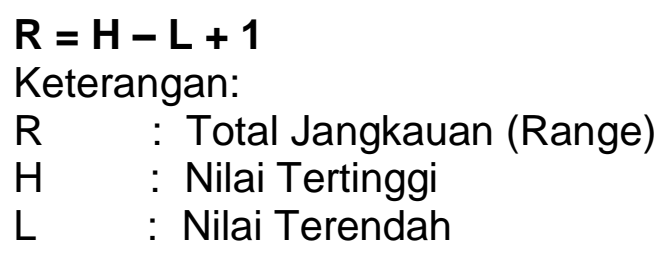

Selanjutnya dicari interval dengan menggunakan rumus sebagai berikut:<smiles>[R][R]([X])=[V]</smiles>

Keterangan :

I : Nilai Interval

R : Jangkauan (Range)

$\mathrm{K} \quad$ : Jumlah kelas yang dikehendaki

\section{HASIL PENELITIAN DAN PEMBAHASAN}

Penelitian ini dilakukan untuk mengetahui efektivitas pembelajaran daring pada kegiatan belajar mengajar praktik dalam mata pelajaran pendidikan jasmani di SMP N 4 Sungai Penuh. Data diperoleh dengan menggunakan kuesioner online menggunakan Google Formulir yang berisi pernyataan untuk mengetahui efektivitas pembelajaran daring pada kegiatan belajar mengajar praktik dalam mata pelajaran pendidikan jasmani di SMP N 4 Sungai Penuh. Selanjutnya hasil kuesioner tersebut dianalisis menggunakan program excel dan IBM SPSS 20. Hasil analisis yang diperoleh sesuai dengan rumusan masalah dapat dilihat sebagai berikut:

1. Indikator Akses Internet dalam Pembelajaran Daring

Analisis deskriptif pada indikator akses internet dengan jumlah item pernyataan sebanyak 10 butir, diperoleh hasil sebagai berikut: 
Tabel 1 Indikator Akses Internet dalam Pembelajaran Daring

\begin{tabular}{ccc}
\hline Jawaban & Frekuensi & Persentase \\
\hline Sangat Setuju & 232 & $23,20 \%$ \\
\hline Setuju & 357 & $35,70 \%$ \\
\hline Netral & 241 & $24,10 \%$ \\
\hline Tidak Setuju & 92 & $9,20 \%$ \\
\hline Sangat Tidak Setuju & 78 & $7,80 \%$ \\
\hline Total & $\mathbf{1 0 0 0}$ & $\mathbf{1 0 0 \%}$ \\
\hline
\end{tabular}

Berdasarkan pada table 1 diperoleh gambaran akses internet dalam pembelajaran daring yang dapat disajikan dalam diagram batang pada gambar sebagai berikut:

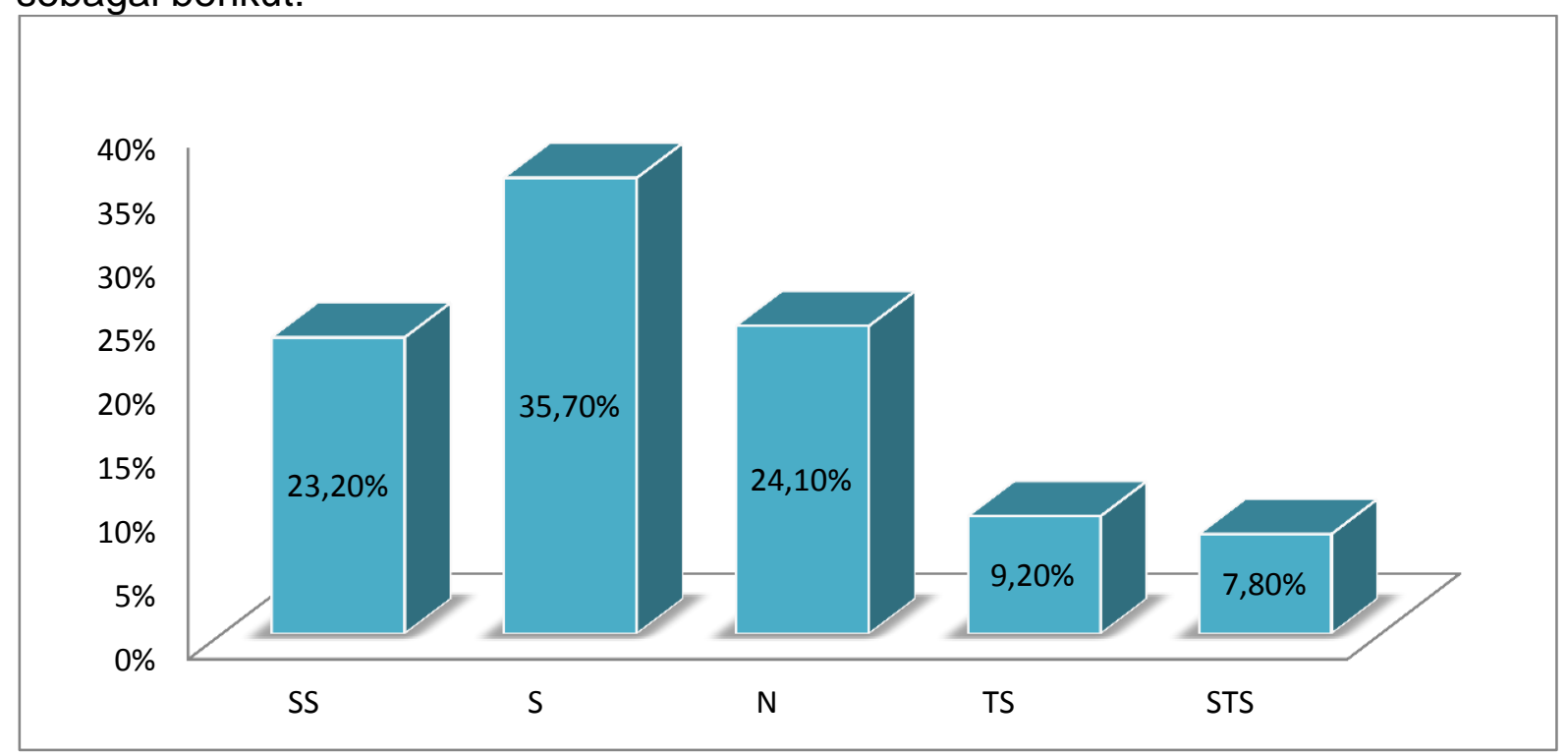

Gambar 1. Diagram Akses Internet dalam Pembelajaran Daring

Berdasarkan tabel 1 dan gambar 2 dapat diketahui bahwa sebanyak 23,20\% siswa sangat setuju bahwa akses internet di Sungai Penuh masih kurang baik, $35,70 \%$ menjawab setuju, 24,10\% menjawab netral, 9,20\% menjawab tidak setuju dan $7,80 \%$ menjawab sangat tidak setuju. Dari data tersebut dapat disimpulkan bahwa akses internet dalam pembelajaran daring di Sungai Penuh tergolong rendah atau masih kurang baik.

2. Indikator Pemahaman Materi dalam Pembelajaran Daring

Analisis deskriptif pada indikator pemahaman materi dalam pembelajaran daring dengan jumlah item pernyataan sebanyak 10 butir, diperoleh hasil sebagai berikut:

Tabel 2 Indikator Pemahaman Materi dalam Pembelajaran Daring

\begin{tabular}{ccc}
\hline Jawaban & Frekuensi & Persentase \\
\hline Sangat Setuju & 256 & $25,60 \%$ \\
\hline Setuju & 362 & $36,20 \%$ \\
\hline Netral & 216 & $21,60 \%$ \\
\hline Tidak Setuju & 84 & $8,40 \%$ \\
\hline Sangat Tidak Setuju & 82 & $8,20 \%$ \\
\hline Total & $\mathbf{1 0 0 0}$ & $\mathbf{1 0 0 \%}$
\end{tabular}


Berdasarkan pada tabel 2, diperoleh gambaran pemahaman materi dalam pembelajaran daring yang dapat disajikan dalam diagram batang pada gambar sebagai berikut:

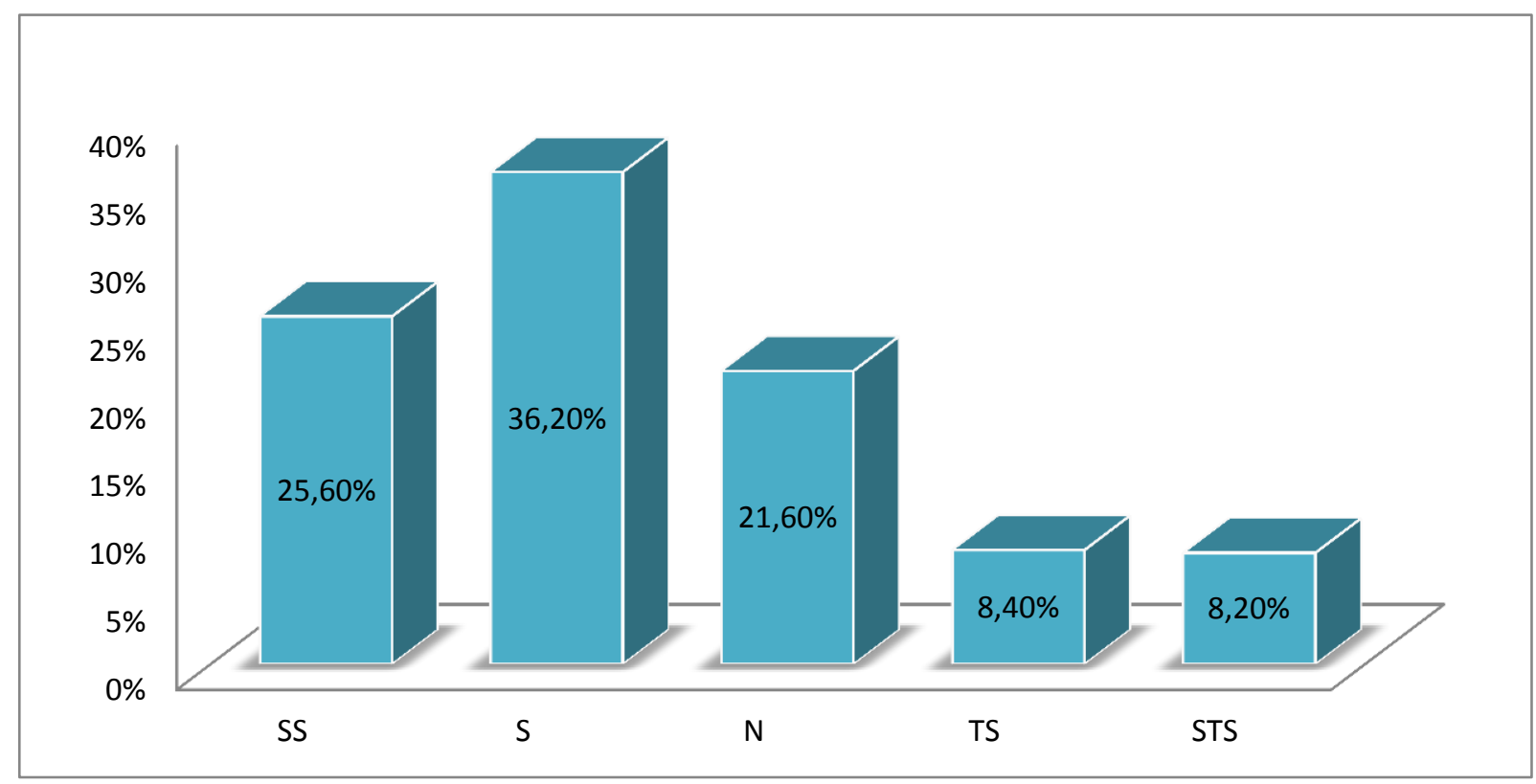

Gambar 2. Diagram Pemahaman Materi dalam Pembelajaran Daring

Berdasarkan table 2 dan gambar 2 diatas dapat diketahui bahwa sebanyak $25,60 \%$ siswa sangat setuju bahwa kurangnya pemahaman materi pembelajaran pada saat pembelajaran daring, 36,20\% menjawab setuju, 21,60\% menjawab netral, $8,40 \%$ menjawab tidak setuju, dan $8,20 \%$ menjawab sangat tidak setuju. Dari data tersebut dapat disimpulkan bahwa pemahaman materi dalam pembelajaran daring di SMP N 4 Sungai penuh masih kurang.

3. Indikator Keefektifan dalam Pembelajaran Daring

Analisis deskriptif pada indikator keefektifan dalam pembelajaran daring dengan jumlah item pernyataan sebanyak 10 butir, diperoleh hasil sebagai berikut:

Tabel 3 Indikator Keefektifan dalam Pembelajaran Daring

\begin{tabular}{ccc}
\hline Jawaban & Frekuensi & Persentase \\
\hline Sangat Setuju & 250 & $25,00 \%$ \\
\hline Setuju & 352 & $35,20 \%$ \\
\hline Netral & 222 & $22,20 \%$ \\
\hline Tidak Setuju & 94 & $9,40 \%$ \\
\hline Sangat Tidak Setuju & 82 & $8,20 \%$ \\
\hline Total & $\mathbf{1 0 0 0}$ & $\mathbf{1 0 0 \%}$
\end{tabular}

Berdasarkan pada tabel 3 diperoleh gambaran keefektifan dalam pembelajaran daring yang dapat disajikan dalam diagram batang pada gambar sebagai berikut: 


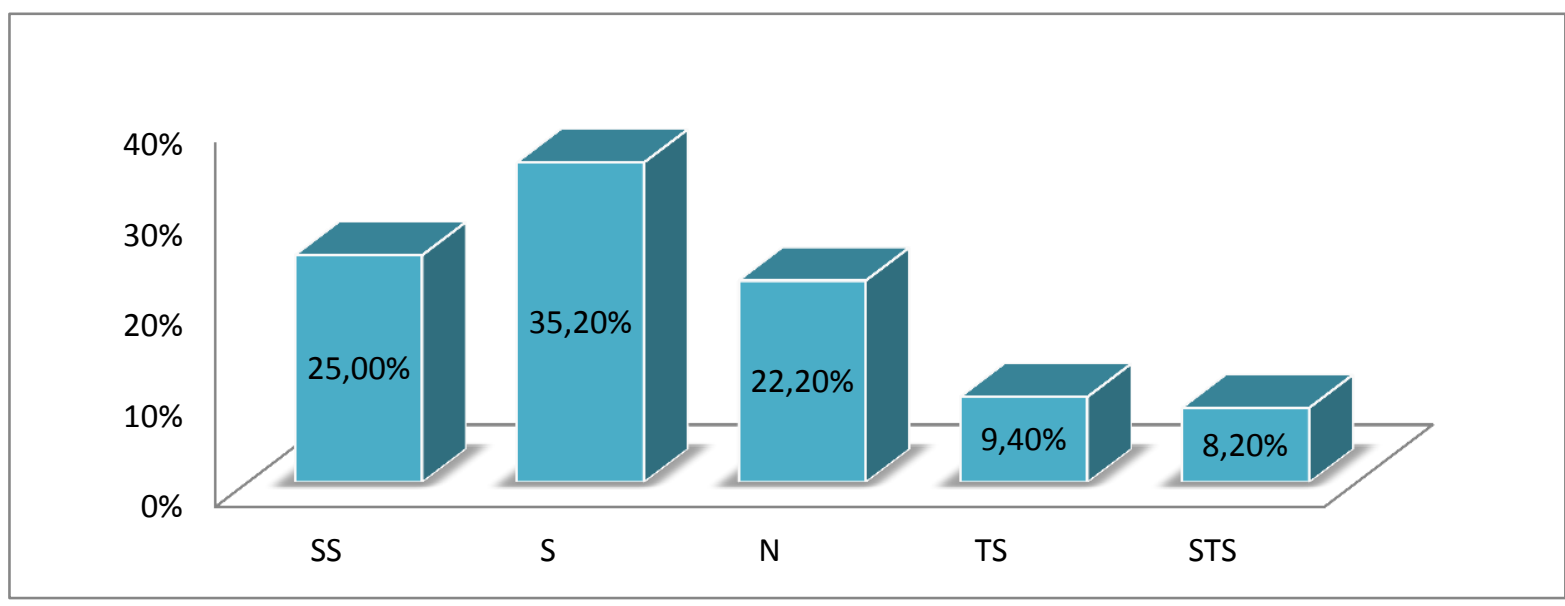

Gambar 3. Diagram Keefektifan dalam Pembelajaran Daring

Berdasarkan tabel 3 dan gambar 3 dapat diketahui bahwa sebanyak 25,00\% siswa sangat setuju bahwa pembelajaran daring kurang efektif, 35,20\% menjawab setuju, 22,20\% menjawab netral, 9,40\% menjawab tidak setuju, dan 8,20\% menjawab sangat tidak setuju. Dari data tersebut dapat disimpulkan bahwa pelaksanaan pembelajaran daring di SMP N 4 Sungai Penuh kurang efektif.

4. Indikator Implementasi Pembelajaran Daring pada KBM Praktik

Analisis deskriptif pada indikator implementasi pembelajaran daring pada KBM praktik dengan jumlah item pernyataan sebanyak 10 butir, diperoleh hasil sebagai berikut:

Tabel 4 Indikator Implementasi Pembelajaran Daring pada KBM Praktik

\begin{tabular}{ccc}
\hline Jawaban & Frekuensi & Persentase \\
\hline Sangat Setuju & 247 & $24,70 \%$ \\
\hline Setuju & 384 & $38,40 \%$ \\
\hline Netral & 225 & $22,50 \%$ \\
\hline Tidak Setuju & 81 & $8,10 \%$ \\
\hline Sangat Tidak Setuju & 63 & $6,30 \%$ \\
\hline Total & $\mathbf{1 0 0 0}$ & $\mathbf{1 0 0 \%}$
\end{tabular}

Berdasarkan pada tabel 4 diperoleh gambaran implementasi pembelajaran daring pada KBM praktik yang dapat disajikan dalam diagram batang pada gambar sebagai berikut:

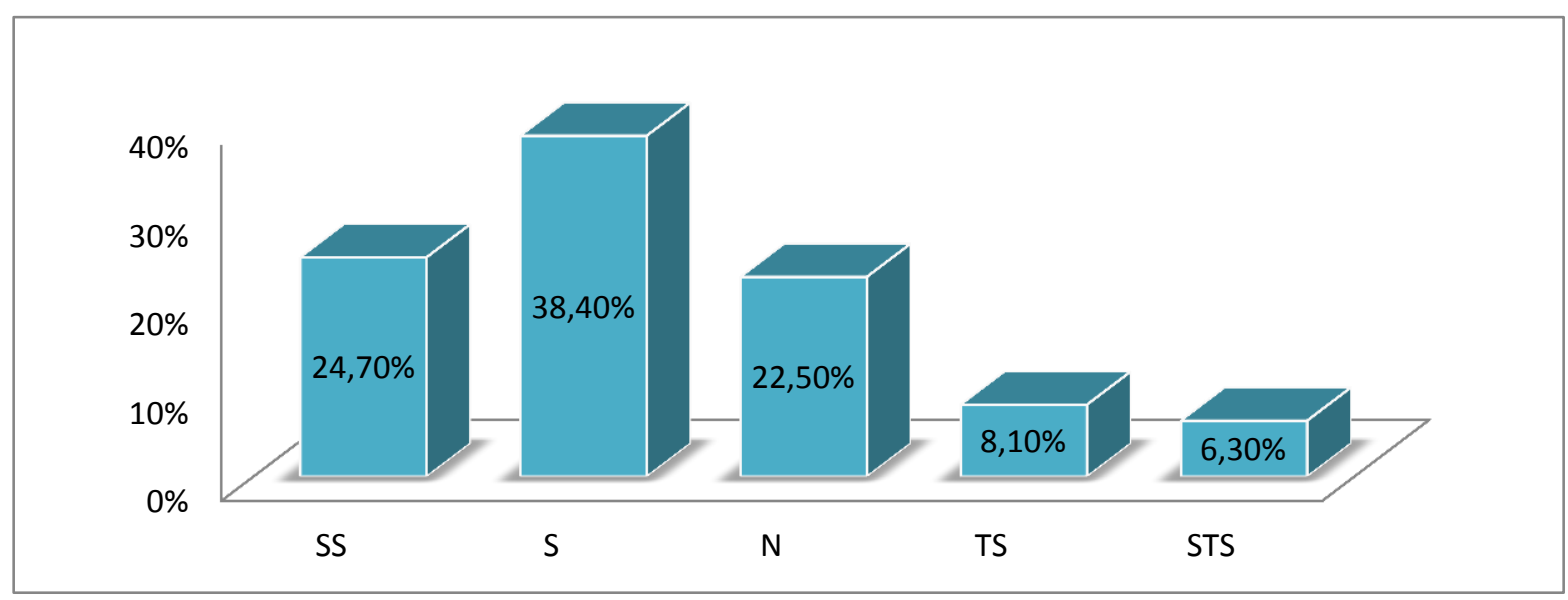

Gambar 4 Implementasi Pembelajaran Daring pada KBM Praktik 
Berdasarkan tabel 4 dan gambar 4 dapat diketahui bahwa sebanyak 24,70\% siswa sangat setuju bahwa kurangnya implementasi pembelajaran daring pada KBM praktik, 38,40\% menjawab setuju, 22,50\% menjawab netral, 8,10\% menjawab tidak setuju, dan $6,30 \%$ menjawab sangat tidak setuju. Dari data tersebut dapat disimpulkan bahwa implementasi pembelajaran daring pada KBM praktik di SMP N 4 Sungai penuh masih kurang.

\section{Uji Normalitas}

Menurut Misbahuddin \& lqbal (2014: 278), uji normalitas data adalah uji prasarat tentang kelayakan data untuk dianalisis dengan menggunakan statistik parametrik atau statistik nonparametrik. Melalui uji ini, sebuah hasil penelitian dapat diketahui bentuk distribusi data tersebut, yaitu berdistribusi normal atau tidak normal.

Uji normalitas dilakukan pada masing-masing variabel penelitian, rumus yang digunakan dalam uji normalitas pada penelitian ini adalah menggunakan rumus Kolmogorov Smirnov, dengan perhitungan menggunakan bantuan program IBM SPSS 20.

Menurut Syofian (2011: 256), data dapat dikatakan berdistribusi normal apabila probabilitas $(\mathrm{sig})>0,05$, maka data dinyatakan berdistribusi normal, apabila probabilitas (sig) $<0,05$, maka data dinyatakan tidak berdistribusi normal.

Berdasarkan hasil perhitungan menggunakan bantuan program IBM SPSS 20, data hasil uji normalitas dapat disajikan pada tabel sebagai berikut:

Tabel 5 Hasil Uji Normalitas

\begin{tabular}{llr}
\hline \multicolumn{3}{c}{ One-Sample Kolmogorov-Smirnov Test } \\
\hline & & Unstandardized Residual \\
\hline $\mathrm{N}$ & & 100 \\
\hline Normal Parameters $^{\mathrm{a}}$ & Mean & .0000000 \\
\cline { 2 - 3 } & Std. Deviation & 4.07145970 \\
\hline Most Extreme Differences & Absolute & .080 \\
\cline { 2 - 3 } & Positive & .080 \\
\cline { 2 - 3 } & Negative &. .056 \\
\hline Kolmogorov-Smirnov Z & & .796 \\
\hline Asymp. Sig. (2-tailed) & & .551 \\
\hline a. Test distribution is Normal. & &
\end{tabular}

Dari tabel 5 dapat diketahui nilai probabilitas signifikasi sebesar 0,551. Nilai ini menunjukkan sig $>\alpha=0,551>0,05$, maka dapat disimpulkan bahwa data berdistribusi normal.

\section{Uji Homogenitas}

Uji homogenitas dilakukan untuk melihat apakah terdapat kesamaan antarvarian atau tidak. Persyaratan agar pengujian homogenitas dapat dilakukan ialah apabila data telah berdistribusi normal. Rumus yang digunakan dalam uji homogenitas pada penelitian ini adalah menggunakan rumus uji One Way ANOVA, dengan perhitungan menggunakan bantuan program IBM SPSS 20.

Menurut Syofian (2015: 287), data dapat dikatakan mempunyai varian yang sama jika probabilitas (sig) $>0,05$, maka data dinyatakan mempunyai varian yang sama, apabila probabilitas (sig) $<0,05$ maka data dinyatakan tidak mempunyai varian yang sama. 
Berdasarkan hasil perhitungan menggunakan bantuan program IBM SPSS 20, data hasil uji homogenitas dapat disajikan pada tabel sebagai berikut:

Tabel 6 Hasil Uji Homogenitas Oneway

Test of Homogeneity of Variances

\begin{tabular}{|c|c|c|c|}
\hline Levene Statistic & df1 & $\mathrm{df} 2$ & Sig. \\
\hline .864 & 16 & 81 & .611 \\
\hline
\end{tabular}

Dari tabel 6 dapat diketahui nilai probabilitas signifikasi sebesar 0,611. Nilai ini menunjukkan sig $>\alpha=0,611>0,05$, maka dapat disimpulkan data mempunyai varian yang sama.

\section{Pengujian Hipotesis}

Suatu hipotesis merupakan suatu pernyataan tentang hubungan yang diduga antara variabel-variabel. Untuk menguji kebenaran sebuah hipotesis digunakan pengujian hipotesis atau pengetesan hipotesis (testing hypothesis). Menurut Husain \& Purnomo (2006: 119), pengujian hipotesis akan membawa kesimpulan untuk menolak atau menerima hipotesis.

Pengujian hipotesis penelitian ini menggunakan teknik uji-t dengan perhitungan menggunakan bantuan program IBM SPSS 20. Adapun hipotesis penelitian dan dasar pengambilan keputusan uji hipotesis pada penelitian ini yaitu:

A. Hipotesis penelitian adalah:

$\mathrm{H}_{\mathrm{a}}=$ "Rendahnya efektivitas pembelajaran daring pada Kegiatan Belajar Mengajar praktik dalam mata pelajaran pendidikan jasmani di SMP N 4 Sungai Penuh".

$\mathrm{H}_{\mathrm{o}}=$ "Tingginya efektivitas pembelajaran daring pada Kegiatan Belajar Mengajar

praktik dalam mata pelajaran pendidikan jasmani di SMP N 4 Sungai Penuh".

B. Dasar pengambilan keputusan uji hipotesis menggunakan uji-t, yaitu:

Jika harga $(\mathrm{sig})<0,05 / \mathrm{t}_{\text {hitung }}>\mathrm{t}_{\text {tabel }}$ maka $\mathrm{H}_{\mathrm{a}}$ diterima

Jika harga $(\mathrm{sig})>0,05 / \mathrm{t}_{\text {hitung }}<\mathrm{t}_{\text {tabel }}$ maka $\mathrm{H}_{\mathrm{a}}$ ditolak

Berdasarkan hasil perhitungan menggunakan bantuan program IBM SPSS 20, data hasil uji hipotesis dengan menggunakan teknik uji-t dapat disajikan pada tabel sebagai berikut:

Tabel 7 Hasil Uji Hipotesis

\section{Coefficients $^{\mathrm{a}}$}

\begin{tabular}{|c|r|r|r|r|r|}
\hline \multirow{2}{*}{ Model } & \multicolumn{2}{|c|}{$\begin{array}{c}\text { Unstandardized } \\
\text { Coefficients }\end{array}$} & $\begin{array}{c}\text { Standardi } \\
\text { zed } \\
\text { Coefficient } \\
\mathrm{s}\end{array}$ & $\mathrm{t}$ & Sig. \\
\cline { 2 - 5 } & $\mathrm{B}$ & Std. Error & \multicolumn{1}{|c|}{ Beta } & & \\
\hline $1 \quad$ (Constant) \\
$\begin{array}{l}\text { Pembelajaran } \\
\text { Daring }\end{array}$ & .4 .079 & 1.276 & & 7.115 & .000 \\
\hline
\end{tabular}

a. Dependent Variable: KBM

Praktik

Dari tabel 7 diatas, dapat diketahui nilai signifikansi sebesar 0,000 dan nilai $t_{\text {hitung }}$ sebesar 4,730. Nilai ini menunjukkan sig $<\alpha=0,000<0,05$, dan $t_{\text {hitung }}>t_{\text {tabel }}=$ 
$4,730>1,660$, maka dapat disimpulkan bahwa $H_{a}$ diterima, yaitu rendahnya efektivitas pembelajaran daring pada kegiatan belajar mengajar praktik dalam mata pelajaran pendidikan jasmani di SMP N 4 Sungai Penuh.

\section{Pembahasan Hasil Analisis Data}

Penelitian ini bertujuan untuk mengetahui efektivitas pembelajaran daring pada kegiatan belajar mengajar praktik dalam mata pelajaran pendidikan jasmani di SMP N 4 Sungai Penuh menggunakan kuesioner online melalui Google Formulir yang dibagikan kepada siswa.

Persentase masing-masing item pada indikator dapat di rekapitulasi pada tabel berikut ini:

Tabel 8 Rekapitulasi Nilai Masing-Masing Item pada Indikator

\begin{tabular}{|c|c|c|c|c|c|}
\hline Indikator & $\begin{array}{l}\text { No. } \\
\text { Item }\end{array}$ & $\begin{array}{c}\text { Nilai } \\
(\%)\end{array}$ & $\begin{array}{c}\text { Persen } \\
(\%)\end{array}$ & $\begin{array}{c}\text { Rata-rata } \\
(\%)\end{array}$ & Kategori \\
\hline \multirow{10}{*}{$\begin{array}{c}\text { Akses internet dalam pembelajaran } \\
\text { daring. }\end{array}$} & 1 & 40,0 & \multirow{10}{*}{48,5} & \multirow{20}{*}{47,7} & \multirow{20}{*}{ Rendah } \\
\hline & 2 & 49,2 & & & \\
\hline & 3 & 46,0 & & & \\
\hline & 4 & 59,0 & & & \\
\hline & 5 & 38,8 & & & \\
\hline & 6 & 49,2 & & & \\
\hline & 7 & 47,0 & & & \\
\hline & 8 & 51,4 & & & \\
\hline & 9 & 52,8 & & & \\
\hline & 10 & 52,0 & & & \\
\hline \multirow{10}{*}{$\begin{array}{l}\text { Pemahaman materi dalam } \\
\text { pembelajaran daring. }\end{array}$} & 11 & 50,6 & \multirow{10}{*}{47,5} & & \\
\hline & 12 & 43,6 & & & \\
\hline & 13 & 40,0 & & & \\
\hline & 14 & 49,2 & & & \\
\hline & 15 & 46,0 & & & \\
\hline & 16 & 59,0 & & & \\
\hline & 17 & 38,8 & & & \\
\hline & 18 & 49,2 & & & \\
\hline & 19 & 47,0 & & & \\
\hline & 20 & 51,4 & & & \\
\hline \multirow{10}{*}{$\begin{array}{c}\text { Keefektifan dalam pembelajaran } \\
\text { daring. }\end{array}$} & 21 & 52,8 & \multirow{10}{*}{48,1} & \multirow{20}{*}{47,7} & \multirow{20}{*}{ Rendah } \\
\hline & 22 & 52,0 & & & \\
\hline & 23 & 50,6 & & & \\
\hline & 24 & 43,6 & & & \\
\hline & 25 & 40,0 & & & \\
\hline & 26 & 49,2 & & & \\
\hline & 27 & 46,0 & & & \\
\hline & 28 & 59,0 & & & \\
\hline & 29 & 38,8 & & & \\
\hline & 30 & 49,2 & & & \\
\hline \multirow{10}{*}{$\begin{array}{l}\text { Implementasi pembelajaran daring } \\
\text { pada Kegiatan Belajar Mengajar } \\
\text { Praktik. }\end{array}$} & 31 & 47,0 & \multirow{10}{*}{46,6} & & \\
\hline & 32 & 51,4 & & & \\
\hline & 33 & 52,8 & & & \\
\hline & 34 & 52,0 & & & \\
\hline & 35 & 50,6 & & & \\
\hline & 36 & 43,6 & & & \\
\hline & 37 & 40,0 & & & \\
\hline & 38 & 38,8 & & & \\
\hline & 39 & 43,6 & & & \\
\hline & 40 & 46,0 & & & \\
\hline
\end{tabular}

Sumber: Olah Data Angket 
Data pada tabel 8 dapat diperoleh informasi bahwa indikator akses internet dalam pembelajaran daring tergolong rendah dengan rata-rata persentase sebesar 48,5\%. Dimana item 1 sebesar 40,0\%, item 2 sebesar 49,2\%, item 3 sebesar $46,0 \%$, item 4 sebesar $59,0 \%$, item 5 sebesar 38,8\%, item 6 sebesar 49,2\%, item 7 sebesar 47,0\%, item 8 sebesar 51,4\%, item 9 sebesar 52,8\%, dan item 10 sebesar $52,0 \%$.

Indikator pemahaman materi dalam pembelajaran daring juga tergolong rendah dengan rata-rata persentase sebesar $47,5 \%$. Dimana item 11 sebesar $50,6 \%$, item 12 sebesar 43,6\%, item 13 sebesar 40,0\%, item 14 sebesar 49,2\%, item 15 sebesar $46,0 \%$, item 16 sebesar $59,0 \%$, item 17 sebesar $38,8 \%$, item 18 sebesar $49,2 \%$, item 19 sebesar $47,0 \%$, dan item 20 sebesar $51,4 \%$.

Indikator keefektifan dalam pembelajaran daring juga masih tergolong rendah dengan rata-rata persentase sebesar 48,1\%. Dimana item 21 sebesar 52,8\%, item 22 sebesar 52,0\%, item 23 sebesar 50,6\%, dan item 24 sebesar 43,6\%, item 25 sebesar 40,0\%, item 26 sebesar 49,2\%, item 27 sebesar 46,0\%, item 28 sebesar $59,0 \%$, item 29 sebesar $38,8 \%$, dan item 30 sebesar $49,2 \%$.

Indikator implementasi pembelajaran daring pada KBM praktik masih sama, tergolong rendah dengan rata-rata persentase sebesar 46,6\%. Dimana item 31 sebesar $47,0 \%$, item 32 sebesar $51,4 \%$, item 33 sebesar $52,8 \%$, item 34 sebesar $52,0 \%$, item 35 sebesar $50,6 \%$, item 36 sebesar $43,6 \%$, item 37 sebesar $40,0 \%$, item 38 sebesar $38,8 \%$, item 39 sebesar $43,6 \%$, dan item 40 sebesar $46,0 \%$.

Data pada nilai persentase dari setiap indikator diatas yaitu indikator akses internet dalam pembelajaran daring dengan nilai rata-rata sebesar $48,5 \%$, indikator pemahaman materi dalam pembelajaran daring dengan nilai rata-rata sebesar $47,5 \%$, indikator keefektifan dalam pembelajaran daring dengan nilai rata-rata sebesar $48,1 \%$, dan indikator implementasi pembelajaran daring pada KBM praktik dengan rata-rata sebesar $46,6 \%$, dapat diambil rata-rata persentase dari ke empat indikator tersebut dengan nilai rata-rata sebesar $47,7 \%$, termasuk dalam kategori rendah.

\section{SIMPULAN}

Hasil penelitian menunjukkan bahwa rendahnya efektifitas pembelajaran daring pada kegiatan belajar mengajar praktik dalam mata pelajaran pendidikan jasmani di SMP N 4 Sungai penuh. Hal ini terlihat dari hasil penelitian yang dijelaskan dalam beberapa indikator yaitu indikator akses internet dalam pembelajaran daring dengan jumlah persentase sebesar $48,5 \%$. Kemudian, pada indikator pemahaman materi dalam pembelajaran daring sebesar $47,5 \%$.

Selanjutnya pada indikator keefektifan dalam pembelajaran daring sebesar $48,1 \%$. Kemudian pada indikator implementasi pembelajaran daring pada kegiatan belajar mengajar praktik sebesar $46,6 \%$. Dari keempat indikator yang telah dijelaskan diatas dapat diambil nilai rata-rata sebesar $47,7 \%$, dari persentase tersebut disimpulkan bahwa efektivitas pembelajaran daring pada kegiatan belajar mengajar praktik dalam mata pelajaran pendidikan jasmani di SMP N 4 Sungai Penuh tergolong rendah.

\section{DAFTAR RUJUKAN}

Arikunto, Suharsimi. 2015. Dasar-Dasar Evaluasi Pendidikan. Jakarta: BumiAksara. Arnesti, N \& Abdul, H. 2015. Penggunaan Media Pembelajaran Online - Offline Dan Komunikasi Interpersonal Terhadap Hasil Belajar Bahasa Inggris. Jurnal Teknologi Informasi \& Komunikasi Dalam Pendidikan. E-ISSN: 2407-7488. Medan: Universitas Negeri Medan. 
Dewi, W, A, F. 2020. Dampak Covid-19 Terhadap Implementasi Pembelajaran Daring di Sekolah Dasar. Jurnal Ilmu Pendidikan Vol 2, No 1. E-ISSN: 26568071. Semarang: Universitas Kristen Satya Wacana.

Indrayana, B dan Ali, S. 2020. Tantangan dan Solusi Pembelajaran Daring Olah Raga di Masa Pandemi Covid-19.Jurnal Indonesian Journal of Sport Science and Coaching.Vol. 02, No.03, (2020). E-ISSN: 2685-9807. Available online at: https://online-journal.unja.ac.id//JSSC/index.

Kemendikbud. 2020. Surat Edaran No. 4 Tahun 2020 Tentang Pelaksanaan Kebijakan Pendidikan Dalam Masa Darurat Penyebaran Coronavirus Disease (Covid-19). Jakarta: Kemendikbud.

Sudijono, A. 2005.Pengantar Statistik Pendidikan. Jakarta: Rajawali.

Sugiyono. 2009. Metode Penelitian Pendidikan Pendekatan Kuantitatif, Kualitatif, dan $R \& D$. Bandung: Alfabet 